\title{
A survey of the sensitivity of fresh clinical isolates to cefuroxime and other antibiotics
}

\author{
L. O. POTASCHMACHER ${ }^{1}$, C. H. DASH ${ }^{2}$, K. A. JEFFERSON ${ }^{1}$, AND $^{2}$ \\ MARGARET R. K. KENNEDY ${ }^{2}$
}

From ${ }^{1}$ Southend General Hospital, Westcliff-on-Sea, Southend, Essex and ${ }^{2}$ Glaxo Group Research Limited, Greenford, Middlesex, UK

SUMMARY The sensitivities to cefuroxime and cephradine of potentially pathogenic bacteria isolated in two British general hospitals comprising 900 beds have been assessed. In a three-month period, 2537 strains were studied; $30 \mu \mathrm{g}$ cefuroxime discs were used with 2511 strains, and cephradine discs of the same strength were used with 2525 strains. The organisms were also examined routinely for sensitivity to other antibiotics. Overall, $91.7 \%$ of the isolates were sensitive to cefuroxime and $85.8 \%$ were inhibited by cephradine, the differences in percentage strain susceptibility to cefuroxime and cephradine being mainly a result of the greater activity of cefuroxime against the Gram-negative bacteria. The wide antibacterial effectiveness of cefuroxime should make it a useful antibiotic for the treatment of serious infections including those conditions in which the causative organism has not been identified.

Cefuroxime is a new semisynthetic cephalosporin antibiotic (O'Callaghan et al., 1976) which has marked stability to staphylococcal penicillinase and to a wide range of $\beta$-lactamases produced by Gramnegative bacteria. The antibiotic penetrates the permeability barrier provided by the cell envelope of most Gram-negative bacteria, the major exception being Pseudomonas aeruginosa, which is impermeable to many antibiotics. Cefuroxime is also active against the penicillin-binding proteins of Gram-negative bacteria, with highest affinity for penicillin-binding protein 3 (Spratt, 1975) which is involved in cell division (N. A. C. Curtis, unpublished data). The contribution that cefuroxime can make in treating infections is dependent upon such factors as its $\beta$-lactamase stability, cell penetrability, the incidence of infection with particular bacteria, and the comparison with current antibiotics. The aim of this study was to assess the usefulness of cefuroxime through analysis of sensitivity tests carried out on consecutive bacterial isolates from all specimens over a predetermined period.

\section{Material and methods}

For three months, from 1 May to 31 July 1977, a

Received for publication 20 February 1979 prospective survey was conducted on all potentially pathogenic bacteria isolated from clinical specimens sent to the hospitals' bacteriology laboratory. No special precautions were taken to exclude identical bacteria from different or the same sources. Clinicians were not encouraged to submit more frequent specimens than was their normal practice. The source of the specimen was recorded (Table 1) and whether they originated from in- or out-patients.

Table 1 Sources of bacteria isolated and the proportion sensitive to cefuroxime

\begin{tabular}{|c|c|c|c|}
\hline \multirow[t]{2}{*}{ Source of specimen } & \multicolumn{3}{|c|}{ Numbers of organisms } \\
\hline & Isolated & $\%$ of total & $\begin{array}{l}\% \text { Sensitive to } \\
\text { cefuroxime }\end{array}$ \\
\hline Wound & 765 & $30 \cdot 2$ & 89.9 \\
\hline Nose & 38 & $1 \cdot 5$ & 100 \\
\hline Throat & 85 & $3 \cdot 4$ & $97 \cdot 6$ \\
\hline Ear & 52 & $2 \cdot 0$ & $94 \cdot 2$ \\
\hline Eye & 179 & $7 \cdot 1$ & $95 \cdot 5$ \\
\hline Blood & 25 & 0.9 & 96.0 \\
\hline Sputum & 126 & $5 \cdot 0$ & $97 \cdot 6$ \\
\hline Urine & 1126 & $44 \cdot 4$ & $91 \cdot 0$ \\
\hline Urethra & 44 & $1 \cdot 7$ & $83 \cdot 7$ \\
\hline High vaginal swab & 66 & $2 \cdot 6$ & $97 \cdot 0$ \\
\hline Faeces & 4 & $0 \cdot 2$ & $100^{*}$ \\
\hline CSF & 1 & 0.03 & $100^{*}$ \\
\hline Bone and fractures & 24 & 0.9 & 95.8 \\
\hline Not specified & 2 & 0.07 & $100^{*}$ \\
\hline
\end{tabular}

*Based on very small numbers. 
ISOLATION AND IDENTIFICATION OF

\section{B ACTERIA}

Organisms were isolated by the techniques routinely used in the study of clinical specimens. Staphylococci were subdivided into Staphylococcus aureus or Staphylococcus epidermidis according to their deoxyribonuclease activity. Lancefield's grouping was performed on $\beta$-haemolytic streptococci; anaerobic Gram-positive cocci were denoted as anaerobic streptococci whereas those requiring only reduced oxygen tension were referred to as microaerophilic streptococci. Clostridia were identified using the methods recommended by Cowan and Steel (1965) and neisseria were screened utilising the serum-free medium of Flynn and Waitkins (1972). Aerobic Gram-negative rods were grouped into lactose and non-lactose fermenters and further subdivided by additional biochemical reactions. In most cases, identification was confirmed by use of the AP1 20E system. Anaerobic Gram-negative rods were identified using the AP1 20A system.

\section{ANTIBIOTIC SUSCEPTIBILITY TESTING}

Antibiotic sensitivities were examined using Oxoid diagnostic sensitivity test (DST) agar; where nutritionally demanding organisms were tested, blood or chocolate agar with a DST agar base was used, each plate containing $12.5 \mathrm{ml}$ of medium. One colony was emulsified in $2 \mathrm{ml}$ peptone water, and a loopful of the suspension was inoculated onto the sensitivity plate and spread with a dry swab. The plates were incubated without prediffusion. Daily control tests were performed with Staph. aureus NCTC 6571, Escherichia coli NCTC 10418, and Ps. aeruginosa NCTC 10662. Isolates were deemed sensitive or resistant by comparison with the control method described by Garrod et al. (1973), except that the term 'moderately resistant' was not used, organisms falling into this category being regarded as resistant. A range of Oxoid Multodisks and Mast and Oxoid single discs was used. Sensitivity to cefuroxime and cephradine was assessed using single $30 \mu \mathrm{g}$ Oxoid discs, and the cultures were recorded as either sensitive or resistant. The other antibiotics used were penicillin $1.5 \mu \mathrm{g}$, gentamicin $10 \mu \mathrm{g}$, cotrimoxazole $25 \mu \mathrm{g}$, cephaloridine $15 \mu \mathrm{g}$ or $25 \mu \mathrm{g}$, tetracycline $10 \mu \mathrm{g}$ or $50 \mu \mathrm{g}$, erythromycin $10 \mu \mathrm{g}$, lincomycin $2 \mu \mathrm{g}$, metronidazole $5 \mu \mathrm{g}$, clindamycin $2 \mu \mathrm{g}$, kanamycin $5 \mu \mathrm{g}$ or $30 \mu \mathrm{g}$, colistin $10 \mu \mathrm{g}$ or $25 \mu \mathrm{g}$, methicillin $25 \mu \mathrm{g}$, and carbenicillin $100 \mu \mathrm{g}$. When two strengths of disc are mentioned, the disc with the greater potency was used for urine isolates.

\section{Results}

During the survey period, 2537 bacterial strains sus- pected of being pathogenic were examined for antibiotic sensitivity. Of the strains isolated, 2511 were examined for cefuroxime sensitivity and 2525 for sensitivity to cephradine. Examination of the remaining strains, most of which were staphylococci or streptococci, was inadvertently omitted.

The types of isolates and their incidence are illustrated in the Figure. The largest single group of organisms was E. coli ( 765 isolates, of which two gave atypical reactions), representing $30.2 \%$ of the total bacterial ecology. The next most frequent isolate was Staph. aureus (359 strains), accounting for $14.2 \%$ of the total population. Other major groups included Klebsiella spp (7.6\%) and Proteus spp (9.6\%). Bacteroides and pseudomonas were isolated with relative infrequency, being $2.0 \%$ and $1.7 \%$ respectively of the population; they generally came from wound swabs but pseudomonas also originated from urine specimens.

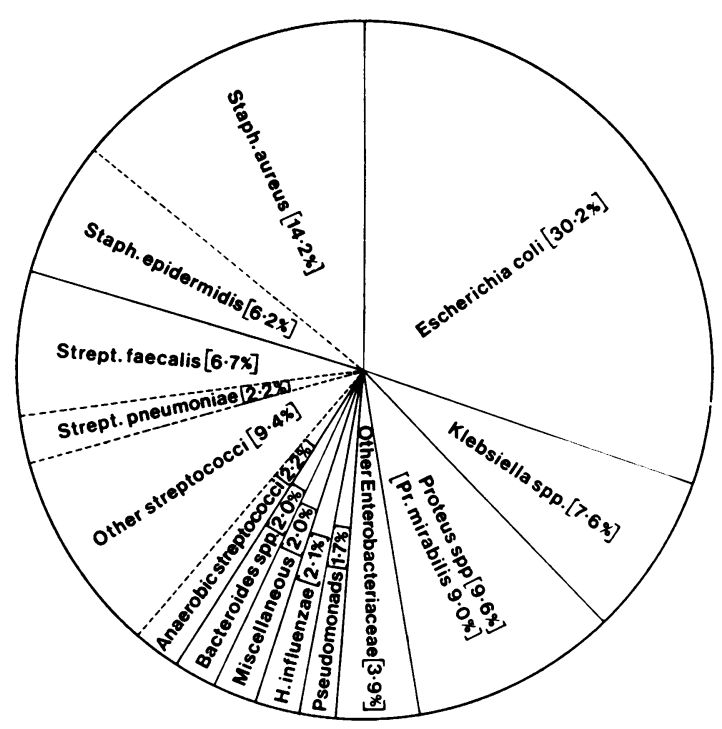

Figure Distribution of 2537 isolates over a three-month period from two British general hospitals. The percentages represent the incidence of the various bacteria.

\section{SENSITIVITIES}

Of the 2511 isolates examined, $2302(91.7 \%)$ were sensitive to cefuroxime, and of the 2525 tested with cephradine, $2167(85 \cdot 8 \%)$ were sensitive. The sensitivities to cefuroxime of organisms from each type of clinical specimen are given in Table 1 . There were no appreciable differences between those bacteria isolated from inpatients and those from outpatients. Although cefuroxime was more consistently active than cephradine against both Gram-positive and 
Gram-negative bacteria, the difference was more marked for the Gram-negative strains, $90.2 \%$ of which were sensitive to cefuroxime compared with only $82.7 \%$ for cephradine. Cefuroxime was active against $93.8 \%$ of the Gram-positive strains, cephradine against $90.3 \%$. In the whole survey there were only 18 strains sensitive to cephradine and resistant to cefuroxime but about nine times as many (168) resistant to cephradine but sensitive to cefuroxime. Most of these latter strains were Enterobacteriaceae. It was thought that the strains accidentally omitted from the sensitivity testing would not significantly have altered the overall results; only 11 organisms were not examined with either cephalosporin and, of those tested with only one cephalosporin, all were sensitive. Cefuroxime and cephradine were more comprehensively tested than the other antibiotics, the activity of which can therefore be compared with the cephalosporins only within specific groups of bacteria.

The results obtained for the staphylococci are shown in Table 2. All but occasional strains of Staph. aureus were sensitive to the cephalosporins, methicillin, and erythromycin, but four-fifths of isolates were resistant to benzylpenicillin, including those from outpatients. Staph. epidermidis strains were cephalosporin sensitive with few exceptions, but methicillin, fusidic acid, and erythromycin were active against less than $90 \%$ of isolates.

Streptococcus pneumoniae strains were fully sensitive to the cephalosporins and to many other antibiotics (Table 3). All Streptococcus mitis (viridans group) strains were cefuroxime sensitive but not all strains were susceptible to the other antibiotics. All but one of the strains tested of streptococci of Lancefield's groups A, B, C, F, and G were sensitive to the first and second generation cephalosporins and benzylpenicillin; the exception, in group $F$, was sensitive to ampicillin. All 62 group $B \beta$-haemolytic streptococci, which were included in this group, were cephalosporin and penicillin sensitive.

There were 171 isolates of Streptococcus faecalis and two of Lancefield's group D, the total forming the fourth largest group of the survey. Cefuroxime was active against two-thirds of the strains, cephradine against half. The remaining 47 miscellaneous streptococci consisted of non-haemolytic aerobes (4), microaerophilic strains (17), and those not typing as groups A-D, F, or G (26). At least $95 \%$ were sensitive to the majority of antibiotics (Table 3). One strain of corynebacterium was tested in the survey; it was isolated in heavy growth from an eye swab.

Table 2 Sensitivities of 516 staphylococci to seven antibiotics

\begin{tabular}{|c|c|c|c|c|c|c|c|c|}
\hline \multirow[t]{2}{*}{ Organism } & \multirow{2}{*}{$\begin{array}{l}\text { Number } \\
\text { isolated }\end{array}$} & \multicolumn{7}{|l|}{ Antibiotic } \\
\hline & & Cefuroxime & Cephradine & Penicillin $G$ & Methicillin & Erythromycin & Fusidic acid & Tetracycline \\
\hline Staph. aureus & 359 & $\begin{array}{l}100 \\
(351)\end{array}$ & $\begin{array}{l}99 \cdot 4 \\
(358)\end{array}$ & $\begin{array}{l}20 \cdot 1 \\
(358)\end{array}$ & $\begin{array}{l}99 \cdot 7 \\
(354)\end{array}$ & $\begin{array}{l}90.8 \\
(358)\end{array}$ & $\begin{array}{l}96.9 \\
(350)\end{array}$ & $\begin{array}{l}83 \cdot 5 \\
(358)\end{array}$ \\
\hline Staph. epidermidis & 157 & $\begin{array}{l}96 \cdot 7 \\
(153)\end{array}$ & $\begin{array}{l}96 \cdot 1 \\
(155)\end{array}$ & $34 \cdot 4$ & $88 \cdot 5$ & $\begin{array}{l}80 \cdot 1 \\
(156)\end{array}$ & $\begin{array}{l}88 \cdot 2 \\
(153)\end{array}$ & $\begin{array}{l}60 \cdot 3 \\
(156)\end{array}$ \\
\hline
\end{tabular}

Figures in parentheses indicate the number of strains tested whenever these were less than the number isolated.

Table 3 Sensitivities of 483 aerobic streptococci to six antibiotics

\begin{tabular}{|c|c|c|c|c|c|c|c|}
\hline \multirow[t]{2}{*}{ Organism } & \multirow{2}{*}{$\begin{array}{l}\text { Number } \\
\text { isolated }\end{array}$} & \multicolumn{6}{|l|}{ Antibiotic } \\
\hline & & Cefuroxime & Cephradine & Penicillin $G$ & Ampicillin & Erythromycin & Tetracycline \\
\hline Strep. pneumoniae & 57 & 100 & 100 & $\begin{array}{l}100 \\
(54)\end{array}$ & 100 & 100 & 100 \\
\hline $\begin{array}{l}\text { Strep. mitis } \\
\text { (viridans group) }\end{array}$ & 53 & $\begin{array}{c}100 \\
(51)\end{array}$ & $\begin{array}{l}96 \cdot 1 \\
(51)\end{array}$ & $\begin{array}{l}94 \cdot 0 \\
(50)\end{array}$ & 100 & $\begin{array}{l}98 \cdot 0 \\
(49)\end{array}$ & $75 \cdot 5$ \\
\hline $\begin{array}{l}\beta \text {-haemolytic streptococci } \\
\text { Lancefield's groups A, B, C, F, G }\end{array}$ & 153 & $99 \cdot 3$ & $99 \cdot 3$ & $\begin{array}{l}99 \cdot 3 \\
(149)\end{array}$ & 100 & $\begin{array}{l}97 \cdot 0 \\
(133)\end{array}$ & $48 \cdot 4$ \\
\hline $\begin{array}{l}\text { Strep. faecalis + } \\
\text { Lancefield's group D streptococci }\end{array}$ & 173 & $\begin{array}{l}67 \cdot 9 \\
(168)\end{array}$ & $\begin{array}{l}49 \cdot 1 \\
(171)\end{array}$ & $\begin{array}{l}1 \cdot 8 \\
(169)\end{array}$ & $\begin{array}{l}98 \cdot 3 \\
(172)\end{array}$ & $\begin{array}{l}83 \cdot 3 \\
(168)\end{array}$ & $38 \cdot 7$ \\
\hline Other aerobic streptococci & 47 & $\begin{array}{l}95 \cdot 7 \\
(46)\end{array}$ & $\begin{array}{l}97 \cdot 8 \\
(46)\end{array}$ & 93.6 & $97 \cdot 9$ & $\begin{array}{l}95 \cdot 2 \\
(4)\end{array}$ & $83 \cdot 0$ \\
\hline Total & 483 & $\begin{array}{l}88 \cdot 0 \\
(475)\end{array}$ & $\begin{array}{l}81 \cdot 1 \\
(477)\end{array}$ & $\begin{array}{l}62 \cdot 9 \\
(469)\end{array}$ & $\begin{array}{l}99 \cdot 0 \\
(482)\end{array}$ & $\begin{array}{l}92 \cdot 2 \\
(449)\end{array}$ & $57 \cdot 3$ \\
\hline
\end{tabular}

Figures in parentheses indicate the numbers of strains tested whenever these were less than the number isolated. 
However, it proved to be a culture of antibioticsensitive Coryne xerosis.

Table 4 shows the susceptibility to eight antibiotics of the enterobacteria isolated. The majority of Klebsiella spp were identified as $K$. pneumoniae and only one $K$. ozaenae was isolated. The indole-positive proteus comprised isolates of $\mathrm{Pr}$. morganii (7), $\mathrm{Pr}$. vulgaris (5), Pr. rettgeri (2), and Pr. inconstans (stuartii) (2), and cefuroxime was active against twice as many of these strains as was cephradine. There were seven Serratia liquefaciens, eight Serratia marcescens, and five unspecified serratia; neither of the cephalosporins was active against any Serr. marcescens strains but gentamicin was active against all. Only one strain each of Enterobacter aerogenes and Enterobacter agglomerans were identified, 33 typing as Enterobacter cloacae. The other six were not fully identified. Over two-thirds of the Enterobacter spp were sensitive to cefuroxime but only about half to cephradine. More strains of Citrobacter freundii were sensitive to cefuroxime than to gentamicin. The pathogens isolated from the four faecal specimens were Shigella flexneri, Shigella sonnei (2), and Salmonella enteritidis, all four being sensitive to most of the antibiotics tested although one Sh. sonnei was resistant to ampicillin. Overall, none of the other antibiotics approached the level of activity of the cephalosporins or gentamicin, and the most potent antibacterial agents against the Enterobacteriaceae were cefuroxime, with $93.5 \%$ tested strains sensitive, and gentamicin which was active against $97.8 \%$ of isolates.

The most frequently encountered aerobic Gramnegative organisms, apart from enterobacteria, were Haemophilus influenzae (54 strains), Acinetobacter spp (19 strains, of which 16 were postively identified as $A$. calcoaceticus), and Neisseria gonorrhoeae (14 strains). All of the gonococci were sensitive to cefuroxime, cephradine, ampicillin, cotrimoxazole, and tetracycline. All of the $H$. influenzae were sensitive to cefuroxime, ampicillin, and tetracycline but only $83.3 \%$ were sensitive to cephradine. Cotrimoxazole was tested against only 38 strains; all were sensitive. Cefuroxime was active against only 11 acinetobacter strains but all were fully sensitive to gentamicin and tetracycline. Other strains isolated included an Aeromonas hydrophila and an Alcaligenes sp; the former was sensitive to cefuroxime but not to cephradine, the latter was resistant to both. The 42 pseudomonads, including one each of Ps. fluorescens and Ps. maltophilia, and 40 Ps. aeruginosa, were resistant to the cephalosporins but sensitive to gentamicin.

Table 5 demonstrates the results for the anaerobes. Metronidazole was tested against 43 of the 50 bacteroides isolates and was active against all of them. These included strains which were not further typed and which could therefore have been Bact. fragilis. Nonetheless, cefuroxime fared better against the bacteroides of unknown species than against the Bact. fragilis strains. Clindaymcin was tested against only 24 strains of bacteroides but was fully active. The only other antibiotic with any significant success against bacteroides was erythromycin but several antibiotics enjoyed reasonable activity against the clostridium isolates and the anaerobic streptococci (Table 4).

\section{Discussion}

Cefuroxime was active against the vast majority of

Table 4 Sensitivities of 1302 Enterobacteriaceae to eight antibiotics

\begin{tabular}{|c|c|c|c|c|c|c|c|c|c|}
\hline \multirow[t]{2}{*}{ Organism } & \multirow{2}{*}{$\begin{array}{l}\text { Number } \\
\text { isolated }\end{array}$} & \multicolumn{8}{|l|}{ Antibiotic } \\
\hline & & Cefuroxime & Cephradine & Gentamicin & Ampicillin & Cotrimoxazole & Carbenicillin & Colistin & Tetracycline \\
\hline E. coli & 765 & $\begin{array}{l}97 \cdot 2 \\
(762)\end{array}$ & $\begin{array}{l}92 \cdot 4 \\
(762)\end{array}$ & $\begin{array}{l}98 \cdot 8 \\
(764)\end{array}$ & $\begin{array}{l}77 \cdot 1 \\
(763)\end{array}$ & $\begin{array}{l}93 \cdot 9 \\
(758)\end{array}$ & $\begin{array}{l}79 \cdot 5 \\
(764)\end{array}$ & $\begin{array}{l}99 \cdot 9 \\
(763)\end{array}$ & $\begin{array}{l}82 \cdot 3 \\
(764)\end{array}$ \\
\hline Klebsiella spp & 193 & $93 \cdot 8$ & $93 \cdot 3$ & $\begin{array}{l}97 \cdot 9 \\
(192)\end{array}$ & $2 \cdot 6$ & $74 \cdot 1$ & $7 \cdot 3$ & $\begin{array}{l}99.0 \\
(192)\end{array}$ & $\begin{array}{l}71 \cdot 4 \\
(168)\end{array}$ \\
\hline Pr. mirabilis & 228 & $94 \cdot 3$ & 78.9 & $98 \cdot 7$ & $\begin{array}{l}89 \cdot 3 \\
(225)\end{array}$ & $\begin{array}{l}82 \cdot 8 \\
(227)\end{array}$ & $95 \cdot 2$ & $\begin{array}{c}0.9 \\
(226)\end{array}$ & $\begin{array}{c}3 \cdot 1 \\
(160)\end{array}$ \\
\hline Indole-positive proteus & 16 & $68 \cdot 8$ & $37 \cdot 5$ & $87 \cdot 5$ & $25 \cdot 0$ & $68 \cdot 8$ & $81 \cdot 3$ & $12 \cdot 5$ & 43.8 \\
\hline Serratia spp & 20 & $25 \cdot 0$ & $20 \cdot 0$ & 100 & $15 \cdot 0$ & $25 \cdot 0$ & $25 \cdot 0$ & $80 \cdot 0$ & $20 \cdot 0$ \\
\hline Enterobacter spp & 41 & $70 \cdot 7$ & $51 \cdot 2$ & $97 \cdot 6$ & $34 \cdot 1$ & $68 \cdot 3$ & $\begin{array}{l}47 \cdot 5 \\
(40)\end{array}$ & $97 \cdot 6$ & $53 \cdot 7$ \\
\hline Citrobacter freundii & 35 & $80 \cdot 0$ & $45 \cdot 7$ & $74 \cdot 3$ & $14 \cdot 3$ & $45 \cdot 7$ & $42 \cdot 9$ & $97 \cdot 1$ & $\begin{array}{l}44 \cdot 1 \\
(34)\end{array}$ \\
\hline $\begin{array}{l}\text { Shigella spp } \\
\text { Salm. enteritidis }\end{array}$ & $\begin{array}{l}3 \\
1\end{array}$ & $\begin{array}{l}100 \\
100\end{array}$ & $\begin{array}{l}100 \\
100\end{array}$ & $\begin{array}{l}100 \\
100\end{array}$ & $\begin{array}{l}66 \cdot 7 \\
100\end{array}$ & $\begin{array}{l}100 \\
100\end{array}$ & $\begin{array}{l}100 \\
100\end{array}$ & $\begin{array}{l}100 \\
100\end{array}$ & $\begin{array}{l}66 \cdot 7 \\
100\end{array}$ \\
\hline Total & 1302 & $\begin{array}{c}93 \cdot 5 \\
(1299)\end{array}$ & $\begin{array}{c}85 \cdot 8 \\
(1299)\end{array}$ & $\begin{array}{c}97 \cdot 8 \\
(1300)\end{array}$ & $\begin{array}{c}63 \cdot 5 \\
(1297)\end{array}$ & $\begin{array}{c}85 \cdot 5 \\
(1294)\end{array}$ & $\begin{array}{c}68 \cdot 8 \\
(1300)\end{array}$ & $\begin{array}{c}80 \cdot 8 \\
(1297)\end{array}$ & $\begin{array}{c}66 \cdot 7 \\
(1207)\end{array}$ \\
\hline
\end{tabular}

Figures in parentheses indicate numbers of strains tested whenever these were less than the number isolated. 
Table 5 Sensitivities of 105 anaerobic organisms to eight antibiotics

\begin{tabular}{|c|c|c|c|c|c|c|c|c|c|}
\hline \multirow[t]{2}{*}{ Organism } & \multirow{2}{*}{$\begin{array}{l}\text { Number } \\
\text { isolated }\end{array}$} & \multicolumn{8}{|l|}{ Antibiotic } \\
\hline & & Cefuroxime & Cephradine & Metronidazole & Erythromycin & Tetracycline & Clindamycin & Penicillin & Ampicillin \\
\hline Bact. fragilis & 27 & $\begin{array}{l}69 \cdot 2 \\
(26)\end{array}$ & $\begin{array}{l}76.9 \\
(26)\end{array}$ & $\begin{array}{l}100 \\
(23)\end{array}$ & $85 \cdot 2$ & $81 \cdot 5$ & $\begin{array}{l}100 \\
(10)\end{array}$ & $3 \cdot 7$ & $25 \cdot 9$ \\
\hline Bacteroides spp & 23 & $\begin{array}{l}95 \cdot 2 \\
(21)\end{array}$ & $\begin{array}{l}86 \cdot 4 \\
(22)\end{array}$ & $\begin{array}{l}100 \\
(20)\end{array}$ & 100 & $69 \cdot 6$ & $\begin{array}{l}100 \\
(14)\end{array}$ & $21 \cdot 7$ & $69 \cdot 6$ \\
\hline Clostridium spp & 16 & $93 \cdot 8$ & $87 \cdot 5$ & $\begin{array}{l}83 \cdot 3 \\
(6)\end{array}$ & $87 \cdot 5$ & $87 \cdot 5$ & $\begin{array}{l}0 \\
\text { (1) }\end{array}$ & $87 \cdot 5$ & $\begin{array}{l}100 \\
(15)\end{array}$ \\
\hline Anaerobic streptococci & 39 & $97 \cdot 4$ & $97 \cdot 4$ & $\begin{array}{c}100 \\
(33)\end{array}$ & 94.9 & $71 \cdot 8$ & $\begin{array}{l}100 \\
(19)\end{array}$ & $94 \cdot 9$ & $97 \cdot 4$ \\
\hline Total & 105 & $\begin{array}{l}89 \cdot 2 \\
(102)\end{array}$ & $\begin{array}{l}88 \cdot 3 \\
(103)\end{array}$ & $\begin{array}{l}98 \cdot 8 \\
(82)\end{array}$ & $92 \cdot 8$ & $76 \cdot 2$ & $\begin{array}{l}97 \cdot 7 \\
(44)\end{array}$ & $54 \cdot 3$ & $\begin{array}{l}73 \cdot 1 \\
(104)\end{array}$ \\
\hline
\end{tabular}

Figures in parentheses indicate the numbers of strains tested whenever these were less than the number isolated.

both Gram-positive and Gram-negative aerobic and anaerobic bacteria encountered in our study. In many instances, over $90 \%$ of the isolates from each genus were sensitive, and the antibiotic was inactive only against $P$ s. aeruginosa. By comparison with cephradine, cefuroxime was more frequently active against organisms of almost all genera. Our survey yielded similar results on an epidemiological basis to the one carried out by Jones et al. (1977), which covered nearly 6000 strains isolated in four laboratories situated in three widely separated areas of the USA. In both surveys, for example, $E$. coli accounted for over $30 \%$ of isolates. The main differences were a larger proportion of Gram-positive cocci, especially streptococci, and anaerobes in the Southend survey and a greater incidence of enterobacteria and pseudomonas in the USA. The bacteriological data in such surveys do show, however, geographical variation, and the results obtained at Southend may not fully reflect the situation in other general hospitals.

The disc-diffusion method of sensitivity testing does not distinguish degrees of antibiotic susceptibility, but, in general, cefuroxime appears to be more active gravimetrically than cephradine even against sensitive organisms. Disc sensitivity testing, therefore, by a first-generation cephalosporin cannot be reliably used to indicate sensitivity to secondgeneration cephalosporins.

Cefuroxime is highly stable to most $\beta$-lactamases, including the Gram-negative class III enzymes mediated by R-factors (Richmond and Sykes, 1973) and the enzymes produced by staphylococci. This is reflected in the Southend sensitivity patterns for the isolates likely to contain these enzymes. Occasionally, class III $\beta$-lactamases are found in haemophilus and neisseria but were not specifically sought in any of the strains isolated in our survey. Also found are enzymes from class I, and cefuroxime is extremely stable to most of them, although some strains of Bact. fragilis, usually Bact. fragilis ssp fragilis, Ser- ratia spp, and indole-positive proteus can produce enzymes capable of hydrolysing cefuroxime, and this renders such strains resistant to its antibacterial action. Thus one reason why one-third of the Bact. fragilis, one-third of the indole-positive proteus, and three-quarters of the serratia strains were insensitive to the cephalosporins was presumably production of a class I $\beta$-lactamase. The percentage of Bact. fragilis strains resistant to cefuroxime varies considerably among centres (Eykyn et al., 1976; Norrby et al., 1976; Jones et al., 1977) and the proportion of species producing this type of class I enzyme is probably the single most important factor responsible for the variabilities.

Cefuroxime has been shown to penetrate rapidly into the cell walls of most Gram-negative bacteria, and this is a contributory feature of its antibiotic effectiveness, but $P$ s. aeruginosa is relatively impermeable to many antibiotics, including cefuroxime. Despite the stability that cefuroxime has in the presence of the various $\beta$-lactamases that this organism can produce, notably the inducible, chromosomally mediated cephalosporinase described by Sabath and colleagues (1965) and the class III TEM-type enzymes, the species is not susceptible. The inactivity of cefuroxime against one-third of Strep. faecalis strains may be due partly to poor penetration of the antibiotic into the cell wall.

Bacteria from a wide variety of clinical specimens were generally found to be sensitive to cefuroxime (Table 1). However, as other antibiotics were not universally tested in our study, partly because of presumed inactivity, overall comparisons cannot readily be made. Nonetheless it appears that cefuroxime exhibits wider antibacterial activity against current clinical isolates than any other antibiotic in our test schedule. Activity against two-thirds of Strep. faecalis strains and many isolates of Bacteroides spp make significant and clinically important contributions to the wide antibacterial cover afforded by cefuroxime. 
This broad-spectrum activity should make it useful for the treatment of infections requiring prompt parenteral therapy when the causative pathogen has not been identified and is not thought likely to be $P$ s. aeruginosa. In our survey only one of 25 isolates from blood culture was resistant to cefuroxime. Encouraging therapeutic results in septicaemia have been reported by several authors (Gobernado et al., 1977; Shah et al., 1977; Geddes et al., 1978).

The excellent in vitro activity of cefuroxime against Staph. epidermidis and Strep. mitis suggests that it may be useful in infections by those bacteria and especially in cases of endocarditis. The low toxicity of cefuroxime would be an additional benefit in these circumstances. All of the Lancefield's group B $\beta$ haemolytic streptococci were sensitive to cefuroxime, which promises that it may find a place in perinatal medicine although the fulminating course of neonatal infections by group B streptococci is a disadvantage for all antibiotics.

Therapeutic concentrations of cefuroxime occur in the cerebrospinal fluid in meningitis (Kuzemko and Walker, 1977; Norrby et al., 1977; Renlund and Pettay, 1977; Wilkinson et al., 1977). Excellent activity against Strep. pneumoniae, Neisseria meningitidis (Fallon and Brown, 1979), H. influenzae, and E. coli make it an appropriate choice for meningitis in any age group.

In many acute chest infections the pathogen is not isolated. However, cefuroxime has good activity against the most likely bacteria, for example, $\boldsymbol{H}$. influenzae and Strep. pneumoniae; in our survey it was active against $97.6 \%$ of 126 isolates from sputum and has been found to be effective clinically (Miki, 1977; Pines et al., 1977; Seed et al., 1977; Bax et al., 1979). Klebsiella spp, although resistant to many antibiotics, are frequently sensitive to cefuroxime. It has been shown to be successful clinically in epidemics caused by such strains (Bint et al., 1979).

Cefuroxime shows great potential for a variety of infections in different sites, and initial clinical studies (Copland, 1977; Daikos et al., 1977; Graninger et al., 1977; Scott, 1977; Geddes et al., 1978) have so far borne out this promise.

We are grateful to the staff of the Department of Microbiology, Southend General Hospital, who made the study possible, and to Mr David Cox, Microbiology Division, Glaxo, for technical assistance. Miss Diana Taylor and Mrs Lorraine Hudson provided assistance with the analysis.

\section{References}

Bax, R. P., Dawson, A. F., Mullinger, Brenda M., and Dash, C.H. (1979). Cefurcxime in the treatment of lower respiratory tract infection. Current Medical Research and Opinion, 5, 772-778.

Bint, A. J., Bullock, D. W., Speller, D. C. E., Stern, S. R., and Turner, A. (1979). Cefuroxime therapy for urinary tract infections caused by a multi-resistant, epidemic Klebsiella aerogenes. Journal of Antimicrobial Chemotherapy, 5, 189-193.

Copland, R. F. P. (1977). The treatment of urinary tract infections with cefuroxime. A comparison of two dosages in urological surgery. In The Early Evaluation of Cefuroxime, edited by E. S. Snell, C. H. Dash, R. D. Foord, and P. W. Muggleton, p. 51. Glaxo, Greenford, Middlesex.

Cowan, S. T., and Steel, K. J. (1965). Manual for the Identification of Medical Bacteria. Cambridge University Press, Cambridge.

Daikos, G. K., Kosmidis, J. C., Stathakis, C., and Giamarellou, H. (1977). Cefuroxime: antimicrobial activity, human pharmacokinetics and therapeutic efficacy. Journal of Antimicrobial Chemotherapy, 3, 555-562.

Eykyn, S., Jenkins, C., King, A., and Phillips, I. (1976). Antibacterial activity of cefuroxime, a new cephalosporin antibiotic, compared with that of cephaloridine, cephalothin, and cefamandole. Antimicrobial Agents and Chemotherapy, 9, 690-695.

Fallon, R. J., and Brown, W. (1979). The sensitivity of strains of $N$. meningitidis to cefuroxime, rifampicin and minocycline. Journal of Antimicrobial Chemotherapy (In press).

Flynn, J., and Waitkins, S. A. (1972). A serum-free medium for testing fermentation reactions in Neisseria gotiorrhoeae. Journal of Clinical Pathology, 25, 525-527.

Garrod, L. P., Lambert, H. P., and O'Grady, F. (1973). Antibiotic and Chemotherapy, 4th edition. Churchill Livingstone, Edinburgh and London.

Geddes, A. M., McGhie, D., Ball, A. P., and Gould, I. (1978). Studies with cefuroxime and cefoxitin. Scandinavian Journal of Infectious Diseases, Supplement 13, 78-81.

Gobernado, M., Gudin, J., Santos, M., Gregori, J., Canton, E., and Ferrando, C. (1977). Cefuroxime in the treatment of bacterial infections in seriously ill patients admitted to an intensive care unit. Proceedings of the Royal Society of Medicine, 70, Supplement 9, 8689.

Graninger, W., Pichler, H., Mulac, K. D., Böhm, M., and Spitzy, K. H. (1977). Clinical evaluation of the effect of cefuroxime in patients with pyelonephritis and osteomyelitis. Proceedings of the Royal Society of Medicine, 70, Supplement 9, 148-150.

Jones, R. N., Fuchs, P. C., Gavan, T. L., Gerlach, E. H., Barry, A. L., and Thornsberry, C. (1977). Cefuroxime, a new parenteral cephalosporin: collaborative in vitro susceptibility comparison with cephalothin against 5,887 clinical bacterial isolates. Antimicrobial Agents and Chemotherapy, 12, 47-50.

Kuzemko, J. A., and Walker, S. R. (1977). Cefuroxime in the treatment of children with bacterial meningitis. In The Early Evaluation of Cefuroxime, edited by E. S. Snell, C. H. Dash, R. D. Foord, and P. W. Muggleton, p. 181. Glaxo, Greenford, Middlesex. 
Miki, F. (1977). An evaluation of cefuroxime in internal medicine. Proceedings of the Royal Society of Medicine, 70, Supplement 9, 107-110.

Norrby, R., Brorsson, J. E., and Seeberg, S. (1976). Comparative study of the in vitro antibacterial activity of cefoxitin, cefuroxime, and cephaloridine. Antimicrobial Agents and Chemotherapy, 9, 506-510.

Norrby, R., Foord, R. D., Price, J. D., and Hedlund, P. (1977). Pharmacokinetic and clinical studies on cefuroxime. Proceedings of the Royal Society of Medicine, 70, Supplement 9, 25-33.

O'Callaghan, C. H., Sykes, R. B., Griffiths, A., and Thornton, J. E. (1976). Cefuroxime, a new cephalosporin antibiotic: activity in vitro. Antimicrobial Agents and Chemotherapy, 9, 511-519.

Pines, A., Raafat, H., Taylor-Pearce, M., Nandi, A. R., Hamad, F. A., Kennedy, M. R. K., and Mullinger, B. M. (1977). Cefuroxime in lower respiratory infections -a preliminary communication. In The Early Evaluation of Cefuroxime, edited by E. S. Snell, C. H. Dash, R. D. Foord, and P. W. Muggleton, p. 95. Glaxo, Greenford, Middlesex.

Renlund, M., and Pettay, O. (1977). Pharmacokinetics and clinical efficacy of cefuroxime in the newborn period. Proceedings of the Royal Society of Medicine, 70, Supplement 9, 179-182.

Richmond, M. H., and Sykes, R. B. (1973). The $\beta$ lactamases of gram-negative bacteria and their possible physiological role. Advances in Microbial Physiology, 9, 31-38.
Sabath, L. D., Jago, M., and Abraham, E. P. (1965). Cephalosporinase and penicillinase activities of a $\beta$-lactamase from Pseudomonas pyocyanea. Biochemical Journal, 96, 739-752.

Scott, A. C. (1977). A clinical and bacteriological study of cefuroxime. Proceedings of the Royal Society of Medicine, 70, Supplement 9, 74-76.

Seed, W. A., Woothipoom, W., Wright, D., and Kinchington, B. (1977). Clinical experience with cefuroxime in pneumonia. In The Early Evaluation of Cefuroxime, edited by E. S. Snell, C. H. Dash, R. D. Foord, and P. W. Muggleton, p. 103. Glaxo, Greenford, Middlesex.

Shah, P. M., Helm, E. B., and Stille, W. (1977). Cefuroxime, a clinical evaluation. Proceedings of the Royal Society of Medicine, 70, Supplement 9, 103-106.

Spratt, B. G. (1975). Distinct penicillin binding proteins involved in the division, elongation, and shape of Escherichia coli K12. Proceedings of the National Academy of Sciences, 72, 2999-3003.

Wilkinson, P. J., Belohradsky, B. H., and Marget, W. (1977). A clinical study of cefuroxime in neonates. Proceedings of the Royal Society of Medicine, 70, Supplement 9, 183-187.

Requests for reprints to: Dr L. O. Potaschmacher, Department of Microbiology, Southend General Hospital, Westcliff-on-Sea, Southend, Essex, UK. 